\title{
Analysis of the condition of karst springs included in the National Groundwater Monitoring Network
}

\author{
Evelina Damyanova
}

${ }^{1}$ National Institute of Meteorology and Hydrology, Bulgaria;

e-mail: evelina.damyanova@meteo.bg

\section{Анализ на сьстоянието на карстовите извори, включени в националната мрежа за мониторинг на подземните води}

Евелина Дамянова

Damyanova, E. 2021. Analysis of the condition of karst springs included in the National Groundwater Monitoring Network. Engineering Geology and Hydrogeology, 35, 31-39.

\begin{abstract}
Approximately $20 \%$ of the monitored points in the National Groundwater Monitoring Network (NGMN) of Bulgaria are karst springs. The number of monitored karst springs is changing over time for various reasons and currently there are 33 springs monitored continuously and 53 on monthly basis. The monitoring points are distributed over 39 karst basins around the whole country. There are between 1 and 5 monitored springs per karst basin and no monitoring points in 23 karst basins. The present analysis includes the determination of some of the main statistical characteristics of karst springs and it is based on the monitoring data series. The obtained data allow us to make some conclusions of the nature of their water regime. Based on the analysis, some suggestions and recommendations are made with regard to improvements in the monitoring of karst springs in Bulgaria.
\end{abstract}

Keywords: karst springs, water flow, groundwater, monitoring, Bulgaria.

Резюме. Приблизително 20\% от наблюдаваните точки в Националната мрежа за мониторинг на подземните води на България са карстови извори. Броят на наблюдаваните карстови извори се променя с течение на времето поради различни причини и в момента има 33 извора, наблюдавани непрекъснато, и 53 на месечна база. Мониторинговите пунктове са разпределени в 39 карстови басейна в цялата страна. На карстов басейн има между 1 и 5 наблюдавани извора, а в 23 карстови басейна няма мониторингови пунктове. Настоящият анализ включва определяне на някои от основните статистически характеристики на карстовите извори и се базира на сериите от мониторингови данни. Получените данни ни позволяват да направим някои изводи за естеството на техния воден режим. На базата на анализа са направени някои предложения и препоръки за подобряване на мониторинга на карстовите извори в България.

Ключови думи: карстови извори, филтрация, подземни води, мониторинг, България. 


\section{Introduction}

Karst groundwater is a major water resource not only in Bulgaria but also worldwide. The prospects for its use are directly related to changes in quantitative and qualitative parameters and is only feasible when there is a good understanding of karst water behavior, features and patterns in temporal and spatial occurrence. The main challenge for the future will be to ensure sufficient water supply for the population and dependent ecosystems in times of drought. That is why the knowledge and study of the groundwater regime and in particular of the karst springs is an important factor for sustainable use. For this purpose, a network for quantitative groundwater monitoring has been set up in the country. The purpose of the present study is to assess the current state of this network and to recommend measures for improving the ability to study the dynamics of karst spring discharge, as a parameter most sensitive to external influences, in order to give a clear idea of the occurring climate changes, as well as the influence of natural or artificial factors.

\section{Karst and karst springs in Bulgaria}

Approximately $22.7 \%$ of the country is covered by outcropping karstified rocks (Popov, 1970). There are different carbonate rocks like limestones, dolomites and marbles of different age, with water-bearing capacity and fracturing. From a hydrogeological point of view, the uncovered rocks which form typical karst aquifers have an important significance. Complex geological and tectonic conditions in the country are the reason for their partial distribution and the formation of numerous individual groundwater basins. A number of challenges have been overcome by many authors to conceptualize the distribution of karst rocks based on their various characteristics (Yaranov, 1959; Boyadjiev, 1964; Popov, 1970; Antonov, Danchev, 1980; Benderev, 2006 a, b). Boyadjiev (1964) was the first scientist who identified over 135 karst basins according to the type of fractured structure (Fig. 1). Yovchev et al. (1969) made a hydrogeological map of Bulgaria in scale 1:200 000 and they defined some regions which are still in use. They divided the country in three primary hydrogeological units - Lower Danube Artesian Basin, Intermediate Zone, and Rila-Rhodope Massif, which are characterized by their features and by the distribution of different types of karst reservoirs.

Later, in 1968-1978, Popov (1970) worked on the geographical distribution of caves and compiled a map of the cave regions in Bulgaria, dividing the country into four districts with 50 karst-speleological areas. Antonov and Danchev (1980) distinguished more than 60 karst basins based on the main physical-geographical and geological factors that determine the groundwater distribution, seasonal changes in water levels, and groundwater flow characteristics. Climate variability and the relief are important and the main physical-geographical factors of influence on the formation of karst. In Bulgaria, the terrain is characterized by high relief, the territory is divided into five altitude zones, $70 \%$ of which are located in altitude zones up to $600 \mathrm{~m}$. The climate is influenced by atmospheric circulation from the Atlantic Ocean, Aegean Sea and the Black Sea. The amount of precipitation and its chemical composition predetermine the development of karst in our country. The geological and tectonic conditions also play an important role. According to Dabovski et al. (2001) the territory of Bulgaria covers parts of two major tectonic units - the Moesian Platform and the northern part of the Alpine Thrust Belt on the Balkans. The most widespread is the mountainous and planar karst type.

At the beginning of the 21 st century, according to the recommendations of the Water Framework Directive (2000), the Bulgarian Directorate Water Management, distinguished and characterized 169 groundwater bodies, 43 of which are partially or completely karst in nature (Fig. 1). 


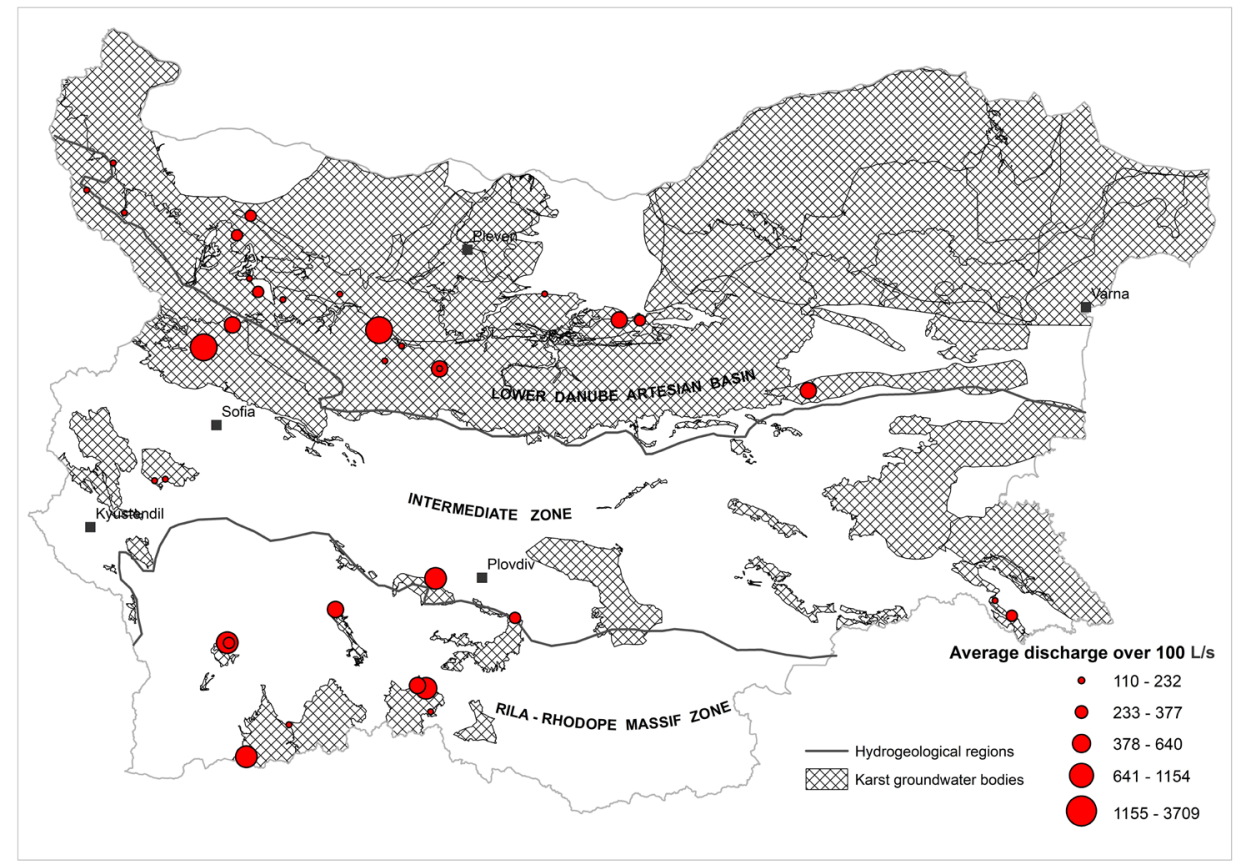

Fig. 1. Hydrogeological regions and karst groundwater bodies.

Фиг. 1. Хидрогеоложки райони и карстови подземни водни тела

In the Lower Danube artesian basin karst rocks and karst waters are related to carbonate rocks that form typical aquifers. The basin is characterized by a planar type of karst. These rocks are karstified to a variable degree and have different permeability. The recharge is mainly from rainfall as well as from deeper aquifers.

Isolated karst basins are formed in the Intermediate Zone and Rila-Rhodope Massif, which are of typical mountainous character. The Intermediate Zone is characterized by karst basins in the Mesozoic Carbonate Complex (Senonian, Triassic, Upper JurassicLower Cretaceous carbonate rocks), and in the Rila-Rhodope Massif karst formed mainly in Pre-Paleozoic(Proterozoic) marbles. The recharge there includes precipitation infiltration and surface run-off entering the developed underground karst-conduit network and discharge occurs through karst springs with significant variability in flow rate. The karst basins are characterized according to their hydrodynamic conditions depending on geology and climate. The seasonal changes depend on the climatic zone in which karst basins are located, as well as the degree of karstification of the area, karst thickness, and permeability, the degree of water retention or saturation, and the discharge conditions. For most karst springs, the recharge occurs mainly through infiltration of precipitation and snowmelt in the high zones of the mountains, but for some springs rivers also contribute to the recharge. The irregular annual distribution of the discharge of springs, especially those with low flow rates, makes them unusable during the dry season. Many karst springs are vulnerable to pollution.

Karst springs are mainly used for water supply, fish farming, and irrigation. They are the major source of water supply in areas where there are no other alternative surface water sources (dams). In Bulgaria, karst springs and their regime are the subject of particular attention by many authors and summarized data are published by Boyadjiev (1964), Antonov, Danchev (1980), Benderev (2006), Damyanova (2015), Benderev, et al. (2020). Their quantitative characteristics depend on catchment areas, 
recharge conditions and degree of karstification. A number of karst springs with discharge exceeding $100 \mathrm{~L} / \mathrm{s}$ have been identified (Fig. 1), 11 of which are in their natural state and other 23 have their seasonal regime disturbed for various reasons.

\section{National hydrogeological network}

Following the Decree of the Council of Ministers dd. 19.03.1956, the Hydrometeorological Service established the Groundwater Department for the purpose of organizing and registering all documentation related to groundwater investigations on a national network. The main tasks of the Hydrometeorological Service were to organize, support, and locate hydrogeological monitoring points for groundwater monitoring on the territory of Bulgaria and aimed to clarify the groundwater regime in different regions that are characterized by specific hydrological conditions and geological setting. This is the beginning of the National Hydrogeological Network including dug wells, boreholes, and springs. The Map of hydrogeological regions in Bulgaria elaborated by Prof. N.A. Plotnikov and others, became the base of the National Hydrogeological Network, which was further developed by Betzinski and Dimitrov (1958). The network included 450 points initially, gradually increasing to 612 points in 1969 and 1257 points in 1985. Between 1990 and 2003, 857 points were excluded, and their number returned at the level of 1958. The monitoring structure was subdivided into two networks - main and departmental. The main hydrogeological network was organized, maintained and used by the Hydrometeorological Service, while the departmental network was managed by all other interested organizations.

The main network comprises two types of monitoring - regional and special. Observations are made on water levels, flow rates and water temperatures. At some monitoring points, samples are taken for chemical analysis to determine major anions and cations, hardness, oxidizability and hydrogen ion concentration (Hydrogeological Yearbook, 1958-1979). After 2010, quality monitoring is being undertaken by the Executive Environment Agency. Collected data are summarized in the hydrogeological yearbooks for the period 1958-1979, and in several other data collections since then.

The National Institute of Meteorology and Hydrology is currently responsible for the hydrogeological monitoring network. It includes 452 monitoring points: 103 springs and 349 dug wells, boreholes and artesian wells. Most of them are monitored on a monthly basis, however there are 62 points that are monitored daily using limnigraphs or data logger. Daily data are collected in 33 springs using a rating curve. The data is being processed in regional centers in Pleven, Varna, Kyustendil and Plovdiv, situated correspondingly in the northern, eastern, western, and southern parts of the country. The Hydrology Department in Sofia is responsible for the general management of the network.

Monthly data on discharge, water levels and water temperature are collected, processed and archived. At some springs, designated as "stations" the water levels are being recorded by data loggers, or by observers on spot between 8 and 20 o'clock every day. Daily data are obtained using rating curves $Q=f(H)$.

The observations and data processing are undertaken by designated teams at the regional centers. Discharge rates by flow meter or volumetric measurements are recorded on a monthly basis. The accuracy of water level measurements by dip meters is $1 \mathrm{~cm}$. There is still no automated system for data collection and the human factor has an influence on the data quality.

\section{Monitoring of karst springs}

The network was set up in 1958 with 169 karst springs, the number of which changed significantly throughout the years, as shown in Figure 2. There are different reasons for the changes, more often being that springs were connected to water systems for supply or electricity generation (Hydrogeological Yearbooks, 1958-1979). 


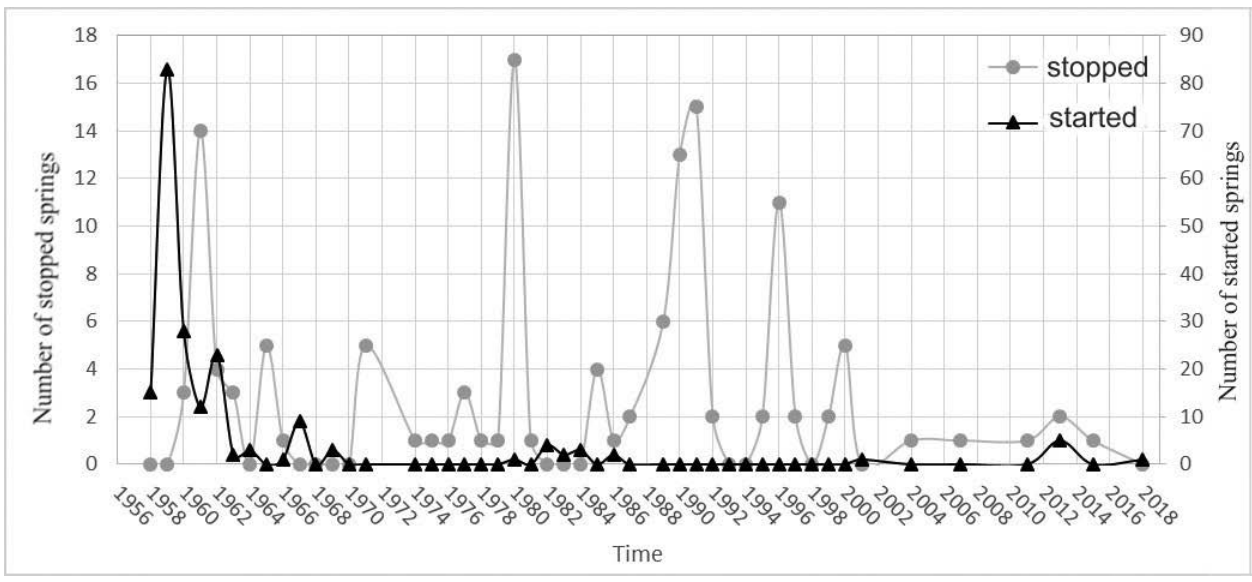

Fig. 2. Distribution of the number of stopped and started for monitoring karst springs over the years Фиг. 2. Разпределение на броя на откритите и закрити за наблюдение карстови извори през годините

Figure 3 shows the monitored karst springs from the beginning until now. They are about $20 \%$ of all monitored points in the Network. For the majority of the springs, discharge rates and water temperature are recorded monthly, fortnightly or daily. The karst springs are unevenly distributed over the territory of the country, as 56 are situated in North Bulgaria. The majority of the springs are at elevations between 300 $\mathrm{m}$ and $900 \mathrm{~m}$ AMSL. Thirty springs are in natural condition, and 56 , or $65 \%$ of the monitored springs are disturbed.

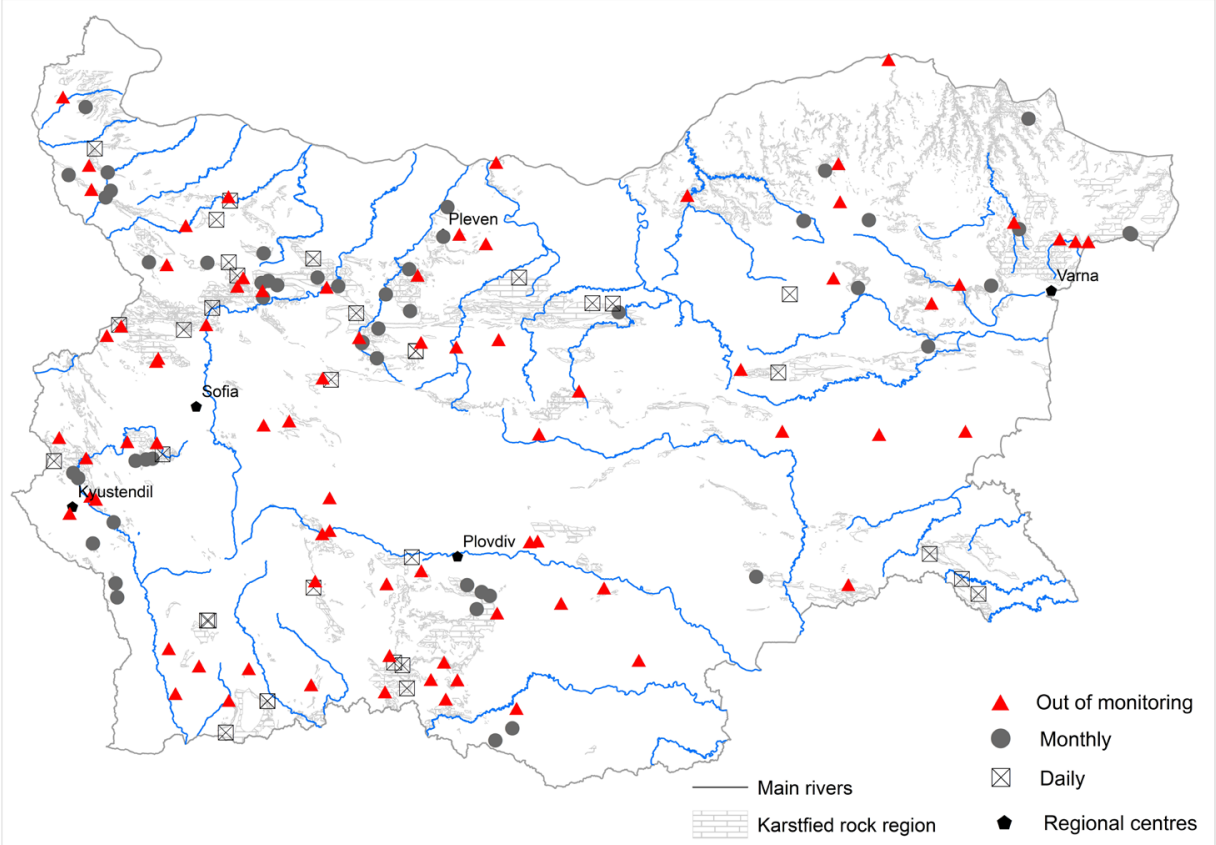

Fig. 3. Distribution of karst springs since the beginning of monitoring Фиг. 3. Разпространение на карстови извори от началото на мониторинга 
The monitoring frequency is monthly for 53 springs, and daily for 33 springs, or $38 \%$ of the total number of monitored springs. Currently, the network comprises of 86 karst springs distributed over 39 larger and smaller karst basins. There are 23 karst basins without monitored springs. The karst springs are unevenly distributed in the 43 individual groundwater bodies, which have partially or completely karst character, and there are no karst springs in 9 groundwater bodies.

\section{Discussion}

Based on the statistical processing of the data series and the results for the main descriptive characteristics of the sources, some useful suggestions can be made for improving, expanding, and optimizing the network.

The financing and maintenance of the network was problematic before year 2000 (Orehova, Roussev, 2004). From 2000 the Ministry of Environment and Water supports the functioning of the Network which would help to take measures to improve and expand the effectiveness of the monitoring network covering karst springs in the country.

These activities are based on the problems identified so far and have both a quantitative and a qualitative aspect. Most of them are guided directly to the network for karst spring monitoring, and others - indirectly to other networks, but related to clarifying the regime of karst waters, their resources, and the effects of natural and anthropogenic factors on them.

In quantitative terms, there is a stable trend of decreasing the number of monitored karst springs - from 144 in 1958-1963 to 86 now.

The main reasons are largely due to lack of financial resources, qualified staff, and technical support, as well as damage without repair of measuring. In some cases, decommissioning of monitoring points is justified by difficult access or because structures of the spring water collection systems do not allow for measurements. As a result, a number of important karst basins and groundwater bodies were left without monitoring points. In the rest of them the karst springs, which characterize the main part of the flow, have disappeared. For this purpose, it is recommended to gradually restore the monitoring at the decommissioned points, initially paying attention to the larger karst springs and those located in groundwater bodies without monitoring points (Table 1, Fig. 4).

Regarding the quality of the measurements, the main problems are related to:

- The main disadvantage is that only a small number of monitoring stations is equipped with data loggers and the quality of data records depends on the human factor.

- Another disadvantage is that for karst springs with disturbed regime, the water quantity that is taken for water supply or for other purposes is not measured. At the majority of the springs, measurements are performed with a flow meter, which is not always the most appropriate approach (especially during dry seasons).

- The specificity of some outlets does not allow their correct measurement.

To solve these problems it is necessary that experts visit each location, undertake a critical review of the conditions, prepare design and construct projects including if required, change of monitoring location, construction of measurement channels or spillways, purchase and installation of suitable measuring equipment, allowing recording and even better online transmission of continuous data series.

It is also needed to appropriately measure deviating water flows - for example for pipelines through a water meter or an external flow meter. 
Table 1. New proposals for expanding the monitoring network

\begin{tabular}{|c|c|c|c|c|c|}
\hline Number & Spring & Year of closure & $Q_{\min }, \mathrm{L} / \mathrm{s}$ & $Q_{\max }, \mathrm{L} / \mathrm{s}$ & $Q_{a v}, \mathrm{~L} / \mathrm{s}$ \\
\hline \multicolumn{6}{|c|}{ First stage } \\
\hline 1 & "Halka bunar", Orizovo & 1990 & 71 & 210 & 121.95 \\
\hline 2 & "Chirpan bunar", Opalchenets & 1997 & 11 & 167 & 52.92 \\
\hline 3 & Cold spring, Belovo & 1971 & 5 & 20 & 12.5 \\
\hline 4 & Hot spring, Belovo & 1999 & 13 & 129 & 58.1 \\
\hline 5 & "Brauna", Smolian & 1960 & 177 & 375 & 276 \\
\hline 6 & "Saint John", Smolian & 1961 & 88.5 & 121 & 104.75 \\
\hline 7 & "Hubcha", Smolian & 1978 & 111 & 2302 & 1206.5 \\
\hline 8 & Spring, Satovcha & 1961 & 2,2 & 4.44 & 3.32 \\
\hline 9 & Spring, Baylovo & 1974 & 34 & 69 & 51.5 \\
\hline 10 & "Arnaut dere", Vlahi & 1961 & 27.3 & 70 & 48.65 \\
\hline \multicolumn{6}{|c|}{ Second stage } \\
\hline 11 & "Mehmeda", Kula & 1990 & 2.04 & 56 & 6.82 \\
\hline 12 & "Vreloto“, v. Targovishte & 2015 & 0.77 & 63 & 19.14 \\
\hline 13 & Spring, Kobiliak & 1980 & 17 & 58 & 45.64 \\
\hline 14 & Spring, Montana & 2007 & 57 & 1256 & 264.11 \\
\hline 15 & "Mishkovo ezero", Ruska Bela & 1962 & 41 & 202 & 121,5 \\
\hline 16 & "Bigora", Zgorigrad & 1996 & 3 & 298 & 28.93 \\
\hline 17 & "The lake“, Cherepish & 1980 & 3.66 & 67 & 35.33 \\
\hline 18 & "Skaklia", Bov & 1990 & 12 & 1256 & 178.2 \\
\hline 19 & "The cave", Tserovo & 1990 & 6 & 299 & 34.72 \\
\hline 20 & Opitzvet springs & 1980 & 147 & 761 & 288 \\
\hline 21 & "The lake", Bezden & 1980 & 31 & 317 & 174 \\
\hline 22 & "Bistrets", Bezden & 1980 & 43 & 1861 & 952 \\
\hline 23 & "Transka Bankia", Bankia & 1960 & 96 & 157 & 126.5 \\
\hline 24 & "Popovets", Etropole & 1965 & 173 & 632 & 402.5 \\
\hline 25 & "Peshta", Etropole & 1987 & 5 & 106 & 13.05 \\
\hline 26 & "Dry lake", Kunino & 1996 & 1.28 & 79 & 9.08 \\
\hline 27 & "The lake", Petarnitsa & 1987 & 17 & 266 & 144.74 \\
\hline 28 & "Waterfall", Glozhene & 1980 & 0 & 266 & 133 \\
\hline 29 & "Sokol monastery", Gabrovo & 1996 & 13 & 100 & 29.27 \\
\hline 30 & Spring, Pepelina & 1961 & 17.8 & 19.4 & 18.6 \\
\hline 31 & Spring, Obrochishte & 2000 & 85.6 & 154 & 103.9 \\
\hline 32 & Spring, Balchik & 2000 & 91.5 & 151 & 121.26 \\
\hline 33 & Spring, Batovo & 2000 & 53,4 & 122 & 80.93 \\
\hline 34 & Springs, Zlatina & 1996 & 162 & 465 & 307 \\
\hline 35 & Springs, Kipilovo & 1961 & 94 & 440 & 267 \\
\hline
\end{tabular}




\begin{tabular}{|c|l|c|c|c|c|}
\hline 36 & "Saint George", Gornoslav & 1971 & 27 & 456 & 241.5 \\
\hline 37 & "Sveti duh", Chepelare & 1980 & 62 & 319 & 190.5 \\
\hline 38 & "Vrisa", Bratzigovo & 1980 & 2.5 & 36 & 19.25 \\
\hline 39 & Spring, Perushtitza & 1971 & 28 & 54 & 41 \\
\hline 40 & Spring, Trigrad & 1996 & 1 & 9503 & 85.46 \\
\hline 41 & "The cave", Velingrad & 1976 & 62 & 129 & 95.5 \\
\hline 42 & "Toplika", Toshkov Chark & 1980 & 93 & 147 & 120 \\
\hline 43 & "Vreloto", Studena & 1975 & 96 & 1041 & 568.5 \\
\hline 44 & Spring, Radomir & 1965 & 57 & 272 & 164.5 \\
\hline 45 & Spring, Trekliano & 1990 & 21 & 390 & 45.64 \\
\hline 46 & "The cold spring", Zemen & 1991 & 12 & 580 & 220.47 \\
\hline 47 & Spring, Breznitsa & 1977 & 107 & 163 & 135 \\
\hline
\end{tabular}

The interpretation of the results obtained from the regime observations of karst springs included in the National Groundwater Monitoring Network, which aims at assessing their resources and the impact of natural and anthropogenic factors on them, often requires climatic and hydrological data but the points for collecting these data are not always located in suitable places. There are often no data on precipitation, temperature, snow cover in the recharge areas, or the flowrate of influential surface waters.

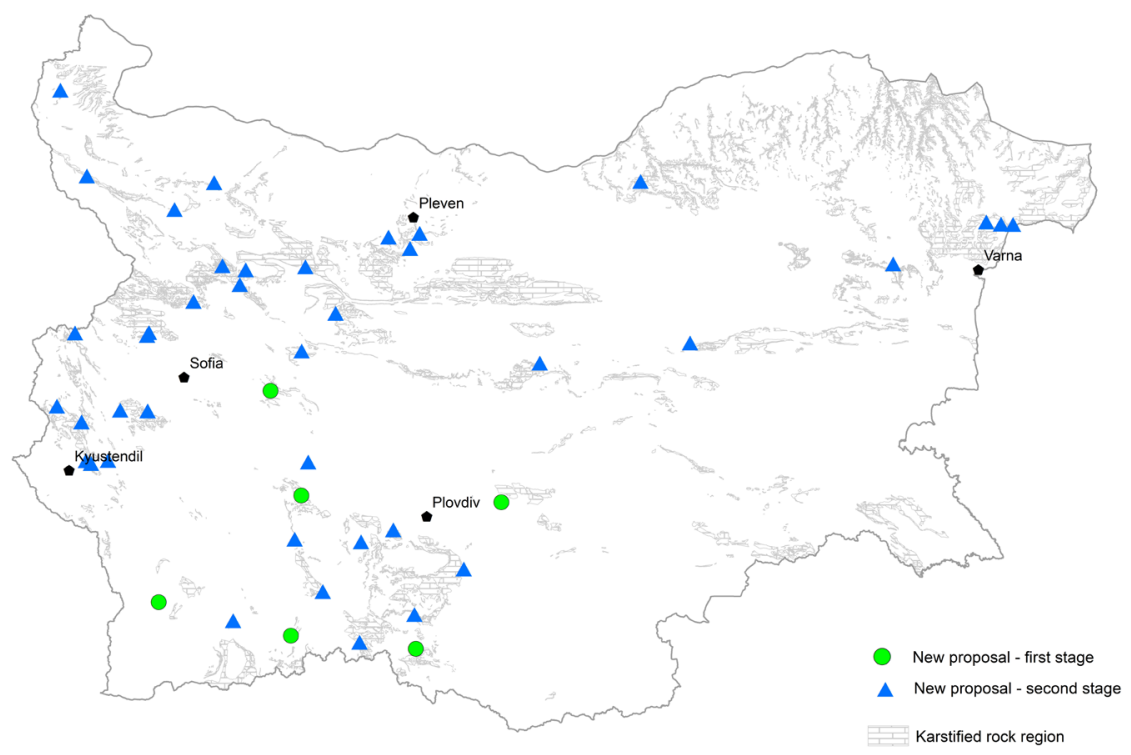

Fig. 4. New proposals for expanding the monitoring network.

Фиг. 4. Нови предложения за разширяване на мониторинговата мрежа. 


\section{Conclusion}

Based on the reviews and evaluations for karst springs, some suggestions and recommendations were made with regard to improvements and expansion for the national network. In the karst basins where there are no monitoring points, it is recommended to restore observation of the springs that have been decommissioned over the years. The frequency of monitoring in some of them may be increased in order to obtain more detailed information about the area. It is highly necessary to equip monitoring stations with automatic recording devices, especially for springs with disturbed regime, or springs with difficult access in winter. Taking measures for the protection of karst groundwater resources and analysis of their condition as a result of the long-term operation will lead to the planning of sustainable use and protection of karst groundwater.

\section{References}

Antonov, H., D. Danchev. 1980. Groundwater in the PRB. Technika, 360 p. (in Bulgarian). Benderev, Al. 2006a. Caves and Karst in Bulgaria. In: Caves and Speleology in Bulgaria (P. Beron, T. Daaliev, Al. Jalov, Eds.). PenSoft, Bulgarian Federation of Speleology and National Museum of Natural History, Sofia. Bulgaria, 104-107.

Benderev, Al. 2006b. Some Important Karstic Region in Bulgaria. In: Caves and Speleology in Bulgaria (P. Beron, T. Daaliev, Al. Jalov (eds.)). PenSoft, Bulgarian Federation of Speleology and National Museum of Natural History, Sofia, Bulgaria.

Benderev, A., S. Shanov, K. Kostov, I. Ivanov. 2020. Hydraulic constructions and facilities on karst in Bulgaria: repercussions influence and problems. Carbonates Evaporites, 35, 18 (2020), Springer, https://doi.org/10.1007/s13146-020-00554-z.

Betzinski, P., D. Dimitrov. 1958. On the issue of construction of hydrogeological network in NR Bulgaria. Structures and tasks of the network. Bull. Inst. of Meteorol. and Hydrol., 5, 14-18 (in Bulgarian).

Boyadjiev, N. 1964. The karst basins in Bulgaria and their subterraneous waters. Bull. Inst. of Meteorol. and Hydrol., 2, 45-96 (in Bulgarian).

Dabovski, C., I. Boyanov, K. Khrischev, T. Nikolov, I. Sapounov, Y. Yanev, I. Zagorchev. 2002. Structure and Alpine evolution of Bulgaria. Geologica Balcanica, 32, 2-4, 9-15.

Damyanova, E. 2015. Characteristics of karst springs used for groundwater monitoring in Bulgaria. Bulgarian Geological Society, National Conference with international participation "GEOSCIENCES 2015”, 143-144 (in Bulgarian).

Orehova, T., R. Roussev. 2004: Overview of National Hydrogeological Network of Bulgaria. BALWOIS 2004, Ohrid, 25-29 May, 3 p.

Popov, V. 1970. Distribution of karst in Bulgaria and some of its features. Reports of Geographical institute, BAS, Vol. XIII (XXIII), 5-19 (in Bulgarian).

Yaranov, D. (ed.). 1959. The karst groundwater in Bulgaria. Collection of studies on the hydrogeology of Bulgaria. Technika, 284 p. (in Bulgarian).

Yovchev, R., L. Berov, I. Stanev. 1969. General hydrogeological conditions and regions, Groundwater, part 2, 81-89 (in Bulgarian).

Постьпила: 29.11.2021

Received: 29 November 2021

Приета: 07.12.2021

Accepted: 07 December 2021 
40 Geological Institute, Bulgarian Academy of Sciences (C) 